\title{
Genomic activation of the EGFR and HER2-neu genes in a significant proportion of invasive epithelial ovarian cancers Joanna Vermeij ${ }^{1,4}$, Erik Teugels ${ }^{1}$, Claire Bourgain' ${ }^{2}$, Ji Xiangming1, Peter in 't Veld $^{2}$, Vanessa Ghislain'², Bart Neyns ${ }^{1,3}$ and Jacques De Grève*1,3
}

Address: ${ }^{1}$ Laboratory for Molecular Oncology, Universitair Ziekenhuis, Vrije Universiteit Brussel, 1090 Brussels, Belgium, ${ }^{2}$ Department of Pathology, Universitair Ziekenhuis, Vrije Universiteit Brussel, 1090 Brussels, Belgium, ${ }^{3}$ Department of Medical Oncology Universitair Ziekenhuis, Vrije Universiteit Brussel, 1090 Brussels, Belgium and ${ }^{4}$ Department of Internal Medicine and Medical Oncology, Ziekenhuis Netwerk Antwerpen (ZNA), 2170 Antwerpen, Belgium

Email: Joanna Vermeij - joanna.vermeij@zna.be; Erik Teugels - eteugels@uzbrussel.be; Claire Bourgain - claire.bourgain@uzbrussel.be; Ji Xiangming - justushall@ hotmail.com; Peter in 't Veld - intveld@vub.ac.be; Vanessa Ghislain - vanessa.ghislain@uzbrussel.be; Bart Neyns - bart.neyns@uzbrussel.be; Jacques De Grève* - jacquesdegreve@skynet.be

* Corresponding author

Published: 8 January 2008

BMC Cancer 2008, 8:3 doi:10.1186/147I-2407-8-3
Received: 10 May 2007

Accepted: 8 January 2008

This article is available from: http://www.biomedcentral.com/l47/-2407/8/3

(C) 2008 Vermeij et al; licensee BioMed Central Ltd.

This is an Open Access article distributed under the terms of the Creative Commons Attribution License (http://creativecommons.org/licenses/by/2.0), which permits unrestricted use, distribution, and reproduction in any medium, provided the original work is properly cited.

\begin{abstract}
Background: The status of the EGFR and HER2-neu genes has not been fully defined in ovarian cancer. An integrated analysis of both genes could help define the proportion of patients that would potentially benefit from targeted therapies.

Methods: We determined the tumour mutation status of the entire tyrosine kinase (TK) domain of the EGFR and HER2-neu genes in a cohort of 52 patients with invasive epithelial ovarian cancer as well as the gene copy number and protein expression of both genes in $3 \mathrm{I}$ of these patients by DGGE and direct sequecing, immunohistochemistry and Fluorescent in Situ Hybridisation (FISH).

Results: The EGFR was expressed in $59 \%$ of the cases, with a $2+/ 3+$ staining intensity in $38 \%$. HER2-neu expression was found in $35 \%$, with a $2 / 3+$ staining in $18 \%$. No mutations were found in exons 18-24 of the TK domains of EGFR and HER2-neu. High polysomy of the EGFR gene was observed in 13\% of the invasive epthelial cancers and amplification of the HER2-neu gene was found in $10 \%$ and correlated with a high expression level by immunohistochemistry.

Mutations within the tyrosine kinase domain were not found in the entire TK domain of both genes, but have been found in very rare cases by others.

Conclusion: Genomic alteration of the HER2-neu and EGFR genes is frequent (25\%) in ovarian cancer. EGFR/HER2-neu targeted therapies should be investigated prospectively and specifically in that subset of patients.
\end{abstract}




\section{Background}

Most ovarian cancers originate in the surface epithelium of the ovary and in particular from invaginations that are remnants of previous ovulation sites. The ErbB family of receptor tyrosine kinases plays a key role in normal ovarian follicle development and cell growth regulation of the ovarian surface epithelium [1].

Overexpression of EGFR (ErbB1) and HER2-neu (ErbB2) has been reported in ovarian cancer [2] and both receptors are commonly co-expressed [3]. In most studies overexpression of HER2-neu has been associated with a worse prognosis while no clear prognostic significance has been established for EGFR (ErbB1) expression [4-9].

Until now it has been unclear to what extent (over) expression of these genes reflects constitutional activation or merely reflects the physiological status of the normal progenitor cells or whether other mechanisms of contitutional activation exist in ovarian cancer.

The prognostic and predictive importance of these receptors and their downstream signalling pathways has been demonstrated in other malignancies and has led to the development of targeted therapies such as monoclonal antibodies (e.g cetuximab, panitunimab, trastuzumab) and small molecules tyrosine kinase receptor inhibitors (e.g gefitinib, erlotinib and more recently dual EGFR/ HER2-neu inhibitors such as lapatinib) in lung cancer, colon cancer and breast cancer.

In breast cancer an increased copy number of HER2-neu defines a patient population that benefits significantly from treatment with trastuzumab and lapatinib.

In non-small cell lung cancer the presence of mutations in the tyrosine kinase domain of EGFR observed in a minority of patients with adenocarcinoma, is a critical determinant for tumour response to tyrosine kinase inhibitors [10-13]. Some studies also identify a high EGFR copy number and protein expression level as molecular predictors of tyrosine kinase efficacy in non-small cell lung cancer (NSCLC) patients [14-17]. For other malignancies such as glioblastomas and colorectal cancer, the predictive significance of molecular markers for benefit from antiEGFR treatment with small molecule tyrosine kinase inhibitors or monoclonal antibodies is proposed but remains to be further defined [18-20].

These targeted therapies are also the subject of clinical trials evaluating their potential in gynecological maligancies.

In an unselected patient population with ovarian cancer and primary peritoneal carcinoma [7] only a modest effect
(4\% response rate) of gefitinib in an unselected patient population was observed suggesting the need to identify molecular markers that are predictive of response.

The EORTC is implementing a phase III clinical trial to examine the effect of adjuvant treatment wit erlotinib in unselected ovarian cancer patients in remission after first line chemotherapy (EORTC protocol 55041).

The aim of the current study was to examine the status of both the EGFR and HER2-neu genes with regard to the mutational status, gene copy number and expression level which could help to enrich for a patient population in which the benefit from targeted therapies could be electively examined.

\section{Methods \\ Design of the study}

The study was done retrospectively on archived ovarian tumour material. Data were compared to literature findings.

\section{Tissues}

Archival ovarian tumour samples, collected from diagnostic or resection specimens of 52 patients were included in the analysis. The tissues were either fixed in Bouin and paraffin embedded or fresh-frozen blocks. The presence of adequate epithelial tumour tissue (80-100\%) in each block and characterization of tumours was determined by a single pathologist (CB).

\section{Mutational analysis}

From some patients biopsies were available from more than one disease site. Genomic DNA was thus extracted from 68 fresh tissue samples obtained from the 52 patients after macrodissection by the same pathologist (CB). Sections of the specimens used for DNA extraction contained a majority proportion of tumour cells. Tissue samples were first digested with proteinase K. DNA was further purified by phenol-chloroform extraction and sodium acetate-ethanol precipitation and subsequently redissolved in a Tris-EDTA buffer. Exons 18-24 encoding the tyrosine kinase domain of both EGFR and HER2-neu genes were amplified by two rounds of polymerasechain-reaction assays with the use of Taq polymerase (Applied Biosystems). The PCR primers were designed with the help of the 'primer 3' program (Table 1 and 2).

PCR products were submitted to Denaturing Gradient Gel Electrophoresis (DGGE), an electrophoretic separation method based on differences in melting behavior of double stranded DNA fragments that is recognized as very sensitive for the detection of mutations [21]. 
Table I: EGFR primers

\begin{tabular}{|c|c|c|c|}
\hline & First step $\left(5^{\prime}-3^{\prime}\right)$ & Second step $\left(5^{\prime}-3^{\prime}\right)$ & Product Size(BP) \\
\hline \multirow[t]{2}{*}{ Exon 18} & F: agcatggtgagggctgag & F: *gctgaggtgacccttgtctc & 258 \\
\hline & $\mathrm{R}:$ acagcttgcaaggactctgg & $\mathrm{R}:$ acagcttgcaaggactctgg & \\
\hline \multirow[t]{2}{*}{ Exon 19} & F: catgtggcaccatctcaca & F: catgtggcaccatctcaca & 179 \\
\hline & R: ccacacagcaaagcagaaac & R: *ggtgtgtcgtttcgtctttg & \\
\hline \multirow[t]{2}{*}{ Exon20 } & F: cgaagccacactgacgtg & F: cgaagccacactgacgtg & 244 \\
\hline & R: ctatcccaggagcgcagac & $\mathrm{R}:$ *ccgtatctcccttccctgat & \\
\hline \multirow[t]{2}{*}{ Exon21 } & F: cctcacagcagggtcttctc & F: cctcacagcagggtcttctc & 215 \\
\hline & $\mathrm{R}:$ aatgctggctgacctaaagc & $\mathrm{R}: *$ ccgactggatttcg & \\
\hline \multirow[t]{2}{*}{ Exon22 } & F: tttttccaacagagggaaact & F: *cactgcctcatctctcacca & 237 \\
\hline & R:aaagaaaatacttgcatgtcagagg & R:aaagaaaatacttgcatgtcagagg & \\
\hline \multirow[t]{2}{*}{ Exon23 } & F: ccactgccttcttttcttgc & $\mathrm{F}: *_{\text {tttcttgcttcatcctctcag }}$ & 205 \\
\hline & R: cagctaggcagtgtggacag & $\mathrm{R}$ : cagctaggcagtgtggacag & \\
\hline \multirow[t]{2}{*}{ Exon24 } & F: gcatcaccaatgccttcttt & F: *gcaatgccatctttatcatttc & 200 \\
\hline & R: actcttcccaatggaagcac & $\mathrm{R}:$ actcttcccaatggaagcac & \\
\hline
\end{tabular}

EGFR primers used for amplification (hemi-nested PCRs).

* indicates that a GC clamp was added at the $5^{\prime}$ end of the primer,

GC clamp: cgccogccgcgeccegcgeccggccegccgeccecgeccg

The power of this technique was evaluated and characterized in several aspects: (1) the hemi-nested PCR is very sensitive since the DNA equivalent of 3 cells was sufficient to generate an amplification signal (2) the DGGE can detect a hemizygous mutation even when the mutant cells used to prepare the DNA sample represented only $25 \%$ of the total cellular amount in dilution experiments, and (3) the 2 most prevalent somatic mutations found in the tyrosine kinase (TK) domain of EGFR (delE746-A750 in exon 19 and L858R in exon 21) in control samples (lung cancer cell lines NCI- H1650 and H255) were consistently detected with this technique. Corresponding white blood cell DNA samples of most patients were available as controls.
DNA fragments presenting an abnormal migration pattern on DGGE were submitted to complete nucleotide sequence analysis with the help of the DNA sequencing kit (Sequenase version 2.0, Amersham) followed by sequencing on gel (Life Technologies). Sequence data were analyzed visually.

\section{Immunohistochemistry and FISH analysis}

Expression of EGFR (ErbB1) and HER2-neu (ErbB2) was determined by immunohistochemistry with the use of the EGFR PharmDx kit (Dako A/S, Glostrup, Denmark) and the Herceptest ${ }^{\mathrm{TM}}$ (Dako A/S). Four micrometer sections of each tumour block were cut. Tests were performed according to the instructions of each kit including the appropri-

Table 2: HER2-neu primers

\begin{tabular}{|c|c|c|c|}
\hline & First step $\left(5^{\prime}-3^{\prime}\right)$ & Second step $\left(5^{\prime}-3^{\prime}\right)$ & Product Size(BP) \\
\hline \multirow[t]{2}{*}{ Exon 18} & F: ccagcactgacccaccac & F: ccagcactgacccaccac & 228 \\
\hline & R: ctcttgcccctcccatca & R: *agaactgccgaccacacc & \\
\hline \multirow[t]{2}{*}{ Exon 19} & F: cccacgctcttctcactcat & F: cccacgctcttctcactcat & 183 \\
\hline & $R$ : agagaccagagcccagacct & R: *gggtccttcctgtcctccta & \\
\hline \multirow[t]{2}{*}{ Exon20 } & F: tgtggtctcccataccctct & F: *ctctcagcgtacccttgtcc & 230 \\
\hline & R: caaagagcccaggtgcatac & $\mathrm{R}$ : caaagagcccaggtgcatac & \\
\hline \multirow[t]{2}{*}{ Exon2I } & F: tacatgggtgcttcccattc & F: tacatgggtgcttcccattc & 201 \\
\hline & R:catgggctagacaccactcc & R: *gctccttggtccttcaccta & \\
\hline \multirow[t]{2}{*}{ Exon22 } & F: tagcccatgggagaactctg & $\mathrm{F}: *$ ctccccacaacacacagttg & 186 \\
\hline & $\mathrm{R}:$ agctctcatcctccctccag & $\mathrm{R}:$ agctctcatcctccctccag & \\
\hline \multirow[t]{2}{*}{ Exon23 } & F: actcctgaccctgtctctgc & $\mathrm{F}:$ actcctgaccctgtctctgc & 220 \\
\hline & $R:$ ctttcatgccccttgtgg & R: *aggacctcccaccctcct & \\
\hline \multirow[t]{2}{*}{ Exon24 } & F: accagactggagggggagt & F: *agaggcagcaagcacacag & 203 \\
\hline & R: gagggtgctcttagccacag & R: gagggtgctcttagccacag & \\
\hline
\end{tabular}

HER2-neu primers used for amplification (hemi-nested PCRs)

* indicates that a GC clamp was added at the 5 ' end of the primer,

GC clamp: cgcccgccgcgccccgcgcccggcccgccgcccc geccg 
ate positive and negative controls. Both kits have been studied in normal ovarian tissue which stains negative for EGFR and HER2-neu.

Tumours were considered EGFR positive if a membranous staining intensity of $\geq 1+$ was observed in more then $1 \%$ percent of the tumour cells (Dako EGFR pharmDX interpretation guide and [22].

HER2-neu was interpreted according to the Herceptest ${ }^{\mathrm{Tm}}$ criteria and scored as $1+, 2+, 3+$. HER2-neu overexpression was defined as weakly $(2+)$ or strong $(3+)$ when complete membrane staining was observed in at least $10 \%$ of the tumour cells.

Fluorescence in situ hybridization (FISH) analysis was performed on cryosections using dual-color DNA FISH probes: for the determination of EGFR gene copy number a LSI EGFR (7p12) probe labeled with SpectrumOrange was used in combination with a CEP7 centromeric probe labeled with Spectrum Green (Abott Molecular, Des Plaines, Il, USA). For the detection of HER2-neu amplification a Pathvysion LSI Her-2 (17q11-12) probe labeled with Spectrum Orange was used in combination with a CEP 17 centromeric probe labeled with Spectrum Green (Abott). Thirty-four samples were available for combined FISH and immunochemistry analysis of EGFR.

EGFR copy number was scored as described by Cappuzzo et al. [14].

For HER2-neu only the cases with a $2+/ 3+$ immunohistochemistry were submitted to FISH analysis $(n=6)$ based on a known correlation established in breast cancer and recent reports in ovarian cancer $[9,23]$.

Amplification for both genes was defined as a ratio EGFR or HER2-neu/CEP $7 \geq 2$.

\section{Statistical analysis}

Associations between factors were analyzed with a Fisher's exact test. A $p$ value of 0.05 was taken as the limit for statistical significance.

\section{Results}

\section{Tumour characteristics}

Fifty-two invasive epithelial ovarian tumours including 27 serous cystadenocarcinoma, 4 mucineus cystadenocarcinoma and 21 endometroid carcinoma were characterized for the presence of mutations in the entire tyrosine kinase domain of both the EGFR and HER2-neu receptors using DGGE and sequence analysis. Of thirty-one invasive cancers, sections containing adequate amounts and quality of tumour were available to be examined for the expression of EGFR and HER2-neu and gene copy number by immunohistochemistry and FISH.

\section{Mutation analysis}

DNA samples were extracted from fresh tumour material obtained from 52 patients. Previous studies done on DNA from distinct tumour sites on part of the cases in this series of ovarian cancers pointed to clonal heterogeneity within the malignant cell population with regard to loss of chromosome 11p [24]. Based on these observations it was decided to examine DNA samples representing different tumour sites when available. A total of 68 DNA samples were thus available for mutation analysis. The complete tyrosine kinase encoding domain was examined. No somatic mutations were detected in exons 18-24 of both receptors (Table 3 ). However, a variant DGGE migration pattern was frequently observed for exon 23 of the EGFR kinase domain. DNA sequencing revealed a point mutation at position $2709 \mathrm{C}>\mathrm{T}$ in this exon. This is a silent mutation (T903T) that does also not seem to influence mRNA splicing [25]. Among the 52 tumours investigated, 13 were heterozygous for this genetic variant, while 3 appeared to be homozygotes. Analysis of blood DNA samples available from 2 of these 3 patients could confirm the homozygosity. We also found this genetic variant in

Table 3: EGFR and HER2-neu status of ovarian tumours

\begin{tabular}{|c|c|c|c|c|c|c|}
\hline \multirow{3}{*}{$\begin{array}{l}\text { Histopathological } \\
\text { subtype }(\mathrm{N}=52)\end{array}$} & \multicolumn{3}{|c|}{ EGFR (ErbB-I) } & \multicolumn{2}{|c|}{ HER2-neu (ErbB-2) } & \multirow{3}{*}{$\begin{array}{l}\text { TKD Mutation } \\
(\mathrm{N}=68)\end{array}$} \\
\hline & $\mathrm{IHC}(\mathrm{N}=3 \mathrm{I})$ & FISH $(N=27)$ & TKD Mutation & $\mathrm{IHC}(\mathrm{N}=3 \mathrm{I})$ & FISH $(\mathrm{N}=6)$ amplification & \\
\hline & $01+2 / 3+$ & $<2$ & & $1+2 / 3+$ & & \\
\hline
\end{tabular}

Adenocarcinoma:

\begin{tabular}{llllllllllllll}
\hline Serous & 27 & 7 & 4 & 8 & 17 & 3 & 34 & 11 & 4 & 4 & 2 & 34 \\
Mucinous & 4 & 1 & 1 & 1 & 3 & 0 & 6 & 3 & 0 & 0 & 0 & 6 \\
Endometroid & 21 & 3 & 2 & 4 & 7 & 1 & 28 & 5 & 2 & 2 & 1 & 28
\end{tabular}

Fifty-two ovarian tumours were analyzed by immunohistochemistry, FISH and mutation status for EGFR (ErBb-I) and HER2-neu (ErBb-2). The IHC scores and definition of gene amplification are specified in the methods section. For EGFR no amplification was found. For HER2-neu the gene copy number was only examined in the 6 cancers with $2 / 3+$ IHC.

$\mathrm{N}=$ number of cases, $\mathrm{P}=$ "high polysomy", $\mathrm{O}=$ absent, $\mathrm{TKD}=$ tyrosine kinase domain. 
the germline DNA of 5 out of $20(25 \%)$ control individuals. Therefore the T903T variant is to be considered a benign polymorfism frequently occuring in the Belgian population.

\section{Protein expression and gene copy number}

EGFR immunostaining could be performed in adequately preserved samples from 31 patients. Positivity was found in 20/31 invasive epithelial cancers (64.5\%) of which 13 ( $42 \%$ ) had an intensity of $\geq 2$ (Table 3 ). FISH analysis for EGFR could be interpreted in 27 invasive epithelial cancers. No gene amplification was found in any of the samples. In 4 cases $(13 \%)$ an increased number of EGFR copies ( $\geq 4$ per nucleus) was detected in the presence of polysomy for chromosome 7 . Such cases were defined as "high polysomy" as previously reported in NSCLC [14]. Immunohistochemistry on these polysomy cases yielded variable results one case being 0 , one case $1+$ and two cases 2+ for EGFR, giving no indication for a correlation with the gene copy number (Fig 1).

HER2-neu immunostaining was positive $(\geq 2+)$ in 6 out of 31 invasive epithelial cancers cases investigated (19\%) of which three cases $(10 \%)$ had an intensity of $3+$ (Table 3 ). Six tumours had $1+$ IHC positivity. Only the cases with $\geq$ $2+$ immunohistochemistry were analyzed by FISH. In the 6 samples that showed either $2+$ or $3+$ positivity in immunohistochemistry HER2-neu gene amplification by FISH analysis was found in 3 cases $(10 \%)$. One sample had a $2+$ IHC score and 5 copies of the HER2-neu gene per nuclear section; two of the cases with a $3+$ IHC score had > 15 copies of the HER2-neu gene per nuclear section (Table 4 and $5)$.

One of the tumours with high level HER2-neu amplification also stained intensily $(3+)$ for EGFR without increased gene copy number. One was EGFR $1+$ and one EGFR negative.

The tumours $(\mathrm{n}=4)$ displaying high polysomy for EGFR all stained negative for HER2-neu.

When the immunopositivity for EGFR and HER2-neu was compared (Table 4) no statistically significant correlation could be found between the expression levels An
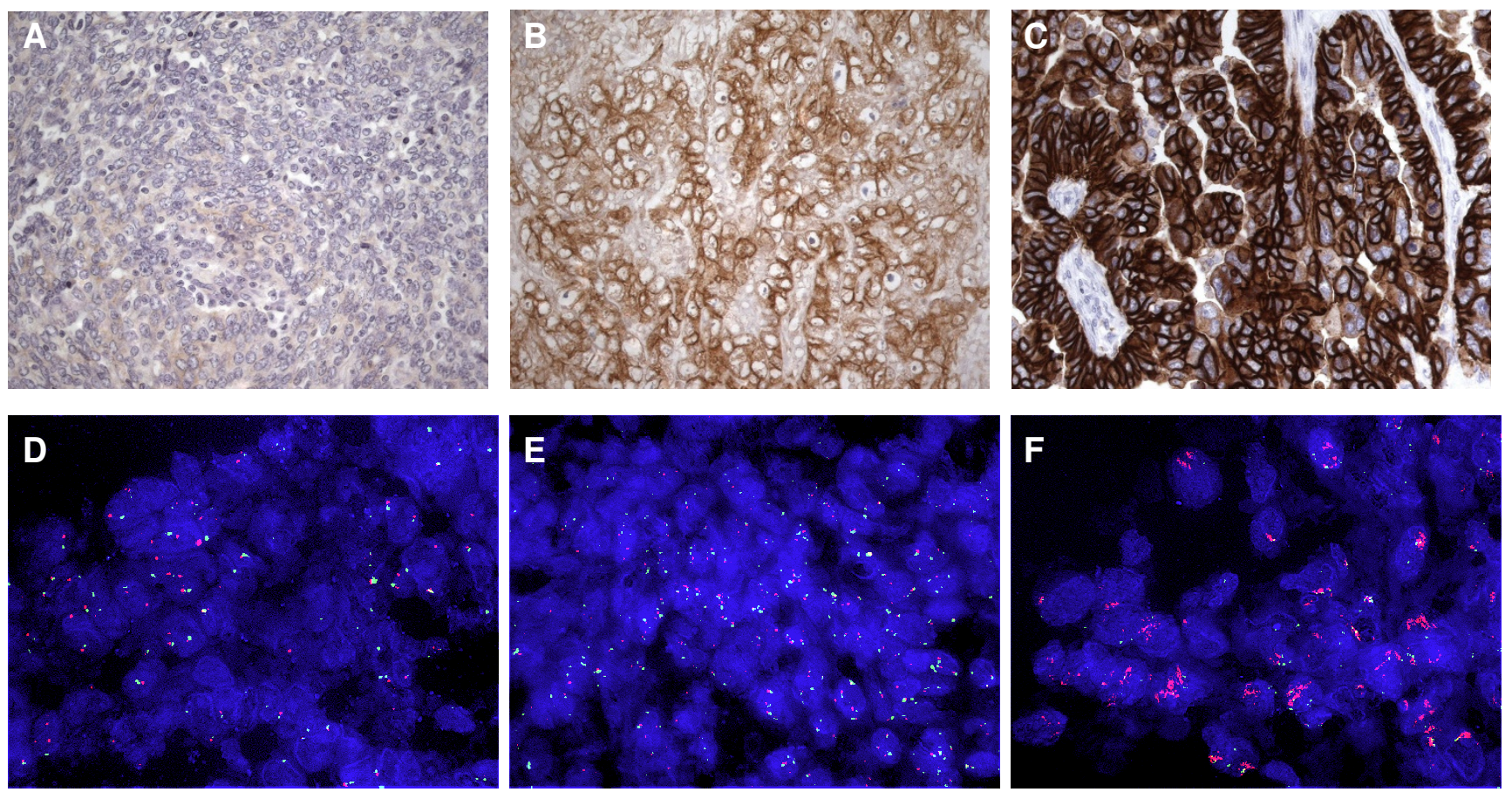

Figure I

Immunohistochemical and FISH analysis of EGFR and HER2-neu on ovarian tumours. A-C : Immunohistochemistry for EGFR and HER2-neu protein expression on paraffin sections from ovarian tumours (all 400x magnification). Examples of an EGFR score 0 (A), EGFR 3+ overexpression (B) and HER2-neu 3+ overexpression (C). D-F : Fluorescence in situ hybridisation for the EGFR and HER2-neu gene on frozen sections from ovarian tumours (all 630x magnification). Examples of a tumour without EGFR amplification (D), a tumour showing polysomy 7 (E) and a tumour with HER2-neu amplification showing clusters of multiple gene copies (F). 
Table 4: EGFR and HER2- neu immunohistochemical expression

\begin{tabular}{llllll}
\hline $\mathrm{N}=3 \mathrm{I}$ & EGFR & & & \\
\hline HER2-neu & & 0 & $1+$ & $2+$ & $3+$ \\
& 0 & 7 & 4 & 6 & 1 \\
& $1+$ & 2 & 2 & 2 & 1 \\
& $2+$ & 1 & 2 & 0 & 0 \\
& $3+$ & $\mathrm{I}$ & 0 & 1 & 1 \\
\hline
\end{tabular}

increased gene copy number for either of these two genes seems mutually exclusive (Table 5).

\section{Discussion}

We have examined the concordant gene status (mutation status and copy number) and expression of both the HER2-neu and EGFR in a series of epithelial ovarian tumours. The mutational status of the genes could be examined in 52 invasive cancers. The IHC was evaluable in 31 and the FISH in 27 cancers.

Ovarian cancer has been examined in the past for some of these characteristics, but in separate reports. The current report is the first to examine the complete tyrosine coding domain of both receptors in a series of ovarian cancers. This analysis was complemented with the determination of gene copy number and immunohistochemical expression in samples in which this was possible, giving comprehensive information in a single series of ovarian cancers and for the two levels of relevance for prognostic or therapeutic applications of these genes: protein expression and gene status.

In breast cancer HER2-neu gene amplification is the major determinant for a potential benefit from trastuzumab treatment. In lung cancer studies $[10,11,26]$ the majority of cancer associated somatic mutations occur in the tyrosine kinase domain of EGFR and Her-2 neu mainly in exon 18-21 and exon 19-20 respectively. Retrospective and prospective data in lung cancer indicate that an EGFR mutation is a stronger predictor for response and outcome under treatment with tyrosine kinase inhibitors than increased copy number $[13,27,28]$.

In many studies in lung cancer, but also in other cancers, EGFR mutation analysis has been restricted to the exons known to be frequently mutated. This might be appropriate in a context of determining potential sensitivity towards small molecule tyrosine kinase inhibitors in a clinical setting of lung cancer. However, when examining other cancer types it remains to be determined whether other mutations might occur. Therefore, we examined the entire tyrosine kinase domain encoding exons (exons 1824) of both EGFR and HER2-neu in a cohort of ovarian cancers. We have found no somatic mutations in $68 \mathrm{sam}-$ ples of 52 invasive epithelial cancers. Others have performed mutation analysis limited to the exons of the tyrosine kinase domain of EGFR known be mutated in lung cancer. Recently 2 activating mutations in the tyrosine kinase domain of EGFR (exon19 (delE746-A750), previously in NSCLC described have been reported in a series of 57 ovarian adenocarcinomas. In one patient this mutation correlated with an objective clinical response to treatment with gefitinib [7].

In another recent study [29] including mutation analysis of exon 18,19 or 21 of the EGFR TK domain in a series of 198 ovarian serous cystadenocarcinoma no mutation was found. This brings the total number of invasive epithelial ovarian cancer cases reported to 305 with a mutation rate of $0.7 \%$ when only the exons known to be mutated in lung cancer are considered.

Activating and tyrosine kinase inhibitor (TKI) sensitizing mutations in the EGFR gene are thus very rare in ovarian cancer in contrast to adenocarcinoma of the lung in which the mutation rate varies between $5-45 \%$ depending on the phenotypic selection criteria and ethnic background of patients $[14,17]$.

All of our patients were of Caucasian origin and it remains to be determined what the mutation rate would be in other ethnicities, for example Asian.

We did not study the extracellular domain of the EGFR receptor which is known to be mutated in glioma but also, albeit rarely in squamous cell lung cancer [30].

HER2-neu mutations have been described in a small subset $(1.6 \%)$ of lung cancers mainly in exon 19-20 [26,31]. These cancers and the patients in whom they occur have the same phenotype as the cancers in which EGFR muta-

Table 5: EGFR and HER2-neu FISH results

\begin{tabular}{|c|c|c|c|c|}
\hline \multicolumn{5}{|c|}{ EGFR $(N=27)$} \\
\hline HER2-neu $(\mathrm{N}=6)$ & & $\leq 2 *$ & High polysomy $\S$ & Amplification** \\
\hline & $\leq 2^{*}$ & 20 & 4 & 0 \\
\hline & Amplification** & 3 & 0 & 0 \\
\hline
\end{tabular}

* Gene copy number, §as defined in [].

** As defined in Methods. 
tions are found. The sigificance of these mutations with regard to sensitivity to HER2-neu inhibition remains undefined. One insertional mutation has been reported in exon 20 of the tyrosine kinase domain of HER2-neu in a series of 198 serous cystadenocarcinomas of the ovary [29]. Thus the cumulative data in 248 invasive epithelial ovarian cancers indicate a HER2-neu mutation rate of 0.4 $\%$.

However the current report is again the only one that examined the complete TK domain. EGFR expression was observed in $64.5 \%$ of invasive cancers, all adenocarcinomas, and in $13 \%$ percent of cases high polysomy as defined in lung cancer was found. This proportion of high polysomy is similar to that found by others [32] in primary ovarian cancers ( $9 / 64$ or $14 \%)$. The cumulative data in 98 patients thus indicate a 13\% rate of high polysomy of the EGFR gene in invasive epithelial ovarian cancer. The classification used in other work [29] is less clear and it is more uncertain what the potential biological significance of low levels of polysomy could be.

No correlation was observed between EGFR expression and EGFR gene copy number. This lack of correlation has also been observed by others [29] and in NSCLC [14].

HER2-neu overexpression was found in $19 \%$ in our series, a proportion similar to other reports [33]. Three tumour samples had a $3+$ staining on immunohistochemistry of which two tumours had a high level of gene amplification. A third sample with a $2+$ IHC positivity had a lesser degree of gene amplification. This suggests that even with this sample size a clear correlation can be detected between expression level and gene copy number, as is also observed in breast cancer. The HER2- neu gene amplification rate is thus a non-negligible $10 \%$ in invasive ovarian cancers. There are currently no other data available in additional patient series. In breast cancer the gene status has the greater relevance with regard to prognostic and predictive implications. In breast cancer sometimes very high (double-digit) levels of gene amplification can be found in clinical samples, which has not been observed yet in ovarian cancer.

The expression status of the EGFR and the HER2-neu genes did not correlate although negativity for EGFR seems to associate with negativity for HER2-neu while vice-versa, negativity for HER2-neu can be associated with high EGFR expression, reflecting the overall lesser positivity rate for HER2-neu versus EGFR. Constitutional activation of the genes through increased copy number seems mutually exclusive.

What are the potential implications with regard to treatment with HER family inhibitors in epithelial ovarian cancer? Dramatic responses observed in lung cancer correlate strongly with the presence of EGFR tyrosine kinase domain mutations. The absence of these mutations in all but a very rare case of ovarian cancer probably will preclude such dramatic responses upon treatment of ovarian cancer with EGFR tyrosine kinase inhibitors. However, these very rare $(<1 \%)$ patients eventually also should receive the opportunity to benefit from the exploration of TKI treatment, which would require the cost of performing a mutation analysis in a large number of patients only to identify rare cases, an effort that currently might not be considered as cost-effective.

When considering the overall data available it can be stated that the EGFR should be examined as a potential target for treatment in a significant minority of ovarium cancer patients and in particular for the $13 \%$ of patients with a cancer having high polysomy. In the BR21 study in NSCLC the strongest markers for survival benefit from treament with erlotinib was EGFR expression and high polysomy [13-17].

Clinical studies involving tyrosine kinase inhibitors in ovarian cancer are ongoing [34] and in the one study that has been published to date, analysis of EGFR gene copy number by FISH or CISH was not included [7]. The limited data available suggest a potential progression-free survival benefit. Four patients have been described with a progression -free survival of over 6 months $(9-32$ months) including one patient carrying an EGFR mutation [7].

If patients with high polysomy would benefit from antiEGFR treatment and in particular TKI in analogy to lung cancer, and given the relatively low proportion of patients having such a high polysomy in their tumours, then it is to be feared that studies in unselected patient populations will dilute out this beneficial effect. Even if these studies are accompagnied by a retrospective analysis of these biomarkers, the results might suffer from insufficient power and biased sample analysis.

Therefore it is important to investigate the efficacy of EGFR inhibitors in (ovarian) cancer in patients prospectively selected for an altered gene status. In that context more uniform definitions of gene amplification and polysomy need to be established. Different study groups tend to use various definitions which makes a comparison of data difficult $[14,29]$.

Monoclonal antibodies (eg cetuximab) directed against the extracellular EGFR domain do not seem to depend on the presence of mutations in the tyrosine kinase domain or gene amplification to induce responses in lung cancer [35]. Currently none of the aspects of EGFR status exam- 
ined here has proven to be informative in predicting response to treatment with these monoclonal antibodies in other cancers [18-20,36].

Studies with these molecules have not been reported in ovarian cancer despite the high rate of immunohistochemical EGFR positivity.

HER2-neu is overexpressed in less than $1 / 5$ of ovarian cancers. In patients selected for HER2-neu overexpression the overall clinical benefit of trastuzumab has been limited [37]. However, in breast cancer IHC expression is less relevant than the gene copy number as assessed by FISH or CISH.

If the analogy with breast cancer holds through, then HER2-neu directed treatment could benefit the ten percent of patients with invasive ovarian cancer identified as having a true gene amplification in their cancer (this study and [33]) and this should be explored prospectively again in this selected population, both as single agent and in combination with chemotherapy to investigate and exploit synergies as observed in breast cancer.

Separately the value of HER2-neu kinase inhibition should be evaluated in the very rare cases with a kinase domain mutation [29].

\section{Conclusion}

We performed an integrated analysis of EGFR and HER2neu protein expression and gene status in a series of epithelial ovarian cancers. Based on our findings and combined with data from the literature it can be concluded that EGFR/HER2-neu directed molecular treatments could benefit and should be investigated in one fourth of all invasive epithelial ovarian cancers.

The knowledge derived from retospective studies like this one should be used in the design of prospective trials investigating the value of EGFR/HER2-neu directed molecular treatments in epithelial ovarian cancer including the need for more uniform definitions of gene amplification and polysomy and selection of a patient population with a known altered gene status.

\section{Competing interests}

The author(s) declare that they have no competing interests.

\section{Authors' contributions}

JV and JDG carried out the design of the study and the analysis and interpretation of the data and drafted the manuscript. JX and ET carried out the mutation analysis. ET was also involved in the design of the study. $\mathrm{CB}$ is the pathologist responsable for the diagnosis, dissection of the tumour material and interpretation of the immunohistochemical staining. P'tV and VG performed the IHC and FISH analysis. BN participated in the draft of the manuscript.

All authors read and approved the final manuscript.

\section{Acknowledgements}

We would like to acknowledge Ms G. van Hassel and Mrs N. Buelens for their excellent technical assistance.

This work was supported by grants from the "Stichting Tegen Kanker" (ET, JDG), the"Wetenschappelijk Fonds Willy Gepts UZ BRUSSEL"( ET, JDG, PiTV) and FWO-Vlaanderen (JV).

J. Vermeij performed part of the work as an aspirant at the FWO- Vlaanderen

\section{References}

I. Conti M, Hseih M, Park JY, Su YQ: Role of the epidermal growth factor network in ovarian follicles. Mol Endocrinol 2006, 20(4):715-723.

2. Maihle NJ, Baron AT, Barrette BA, Boardman $\mathrm{CH}$, Christensen TA, Cora EM, Faupel-Badger JM, Greenwood T, Juneja SC, Lafky JM, Lee $H$, Reiter JL, Podratz KC: EGF/ErbB receptor family in ovarian cancer. Cancer Treat Res 2002, 107:247-58.

3. Ebert AD, Wechselberger C, Martinez-Lacaci I, Bianco C, Weitzel HK, Salomon DS: Expression and function of EGF-related peptides and their receptors in gynecological cancer--from basic science to therapy. J Recept Signal Transduct Res 2000, 20(I): I-46.

4. Elie C, Geay JF, Morcos M, Le Tourneau A, Girre V, Broet P, Marmey $B$, Chauvenet L, Audouin J, Pujade-Lauraine E, Camilleri-Broet S, GINECO Group: Lack of relationship between EGFR - I immunohistochemical expression and prognosis in a multicentre clinical tral of 93 patients with advanced primary ovarian epithelial cancer. Br J Cancer 2004, 91 :470-475.

5. Nielsen JS, Jakobsen E, Holund B, Bertelsens K, Jakobsen A: Prognostic significnace of p53, Her-2 and EGFR overexpression in borderline and epithelial ovarian cancer. Int J Gynecol Cancer 2004, I 4:1086-1096.

6. Psyrri A, Kassar M, Yu Z, Bamias A, Weinberger PM, Markakis S, Kowalski D, Camp RL, Rimm DL, Dimopoulos MA: Effect of epidermal growthfactor receptor expression level on survival in patients with epithelial ovarian cancer. Clin Cancer Res 2005, I I :8637-43.

7. Schilder RJ, Sill MW, Chen X, Darcy KM, Decesare SL, Lewandowski G, Lee RB, Arciero CA, Wu H, Godwin AK: Phase II study of gefitinib in patients with relapsed or persistent ovarian or primary peritoneal carcinoma and evaluation of epidermal growth factor receptor mutations and immunohistochemical expression: a Gynecologic Oncology Group Study. Clin Cancer Res 2005, I I:5539-5548.

8. Verri E, Guglielmini P, Puntoni M, Perdelli L, Papadia A, Lorenzi P, Rubagotti A, Ragni N, Boccardo F: HER2/neu oncoprotein overexpression in epithelial ovarian cancer: evaluation of its prevalence and prognostic significance. Clinical study. Oncology 2005, 68: I54-6I.

9. Steffensen KD, Waldstrøm M, Jeppesen U, Jakobsen E, Brandslund I, Jakobsen A: The prognostic importance of cyclooxygenase 2 and HER2 expression in epithelial ovarian cancer. Int J Gynecol Cancer 2007, I 7:798-807.

10. Lynch TJ, Bell DW, Sordella R, Gurubhagavatula S, Okimoto RA, Brannigan BW, Harris PL, Haserlat SM, Supko JG, Haluska FG, Louis DN, Christiani DC, Settleman J, Haber DA: Activating mutations in the epidermal growth factor receptor underlying responsiveness of non-small-cell lung cancer to gefitinib. NEngl J Med 2004, 350:2129-2139.

II. Paez JG, Janne PA, Lee JC, Tracy S, Greulich H, Gabriel S, Herman P Kaye FJ, Lindeman N, Boggon TJ, Naoki K, Sasaki H, Fujii Y, Eck MJ, Sellers WR, Johnson BE, Meyerson M: EGFR mutations in lung 
cancer: correlation with clinical response to gefitinib therapy. Science 2004, 304:1497-14500.

12. Sordella R, Bell DW, Haber DA, Settleman J: Gefitinib-sensitizing EGFR mutations in lung cancer activate anti-apoptotic pathways. Science 2004, 305: I 163-1167.

13. Inoue A, Suzuki T, Fukuhara T, Maemondo M, Kimura Y, Morikawa N, Watanabe H, Saijo Y, Nukiwa T: Prospective Phase II Study of Gefitinib for Chemotherapy-Naive Patients With Advanced Non-Small-Cell Lung Cancer With Epidermal Growth Factor Receptor Gene Mutations. J Clin Oncol 2006, 24:3340-3346.

14. Cappuzzo F, Hirsch FR, Rossi E, Bartolini S, Ceresoli GL, Bemis L, Haney J, Witta S, Danenberg K, Domenichini I, Ludovini V, Magrini E, Gregorc V, Doglioni C, Sidoni A, Tonato M, Franklin WA, Crino L, Bunn PA Jr, Varella-Garcia M: Epidermal growth factor receptor gene and protein an gefitinib sensitivity in non-small cell lung cancer. J Natl Cancer Inst 2005, 97:643-655.

15. Hirsch FR, Varella-Garcia M, McCoy J, West H, Xavier AC, Gumerlock P, Bunn PA Jr, Franklin WA, Crowley J, Gandara DR, Southwest Oncology Group: Increased epidermal growth factor receptor gene copy number detected by fluorescence in situ hybridization associates with increased sensitivity to gefitinib in patients with bronchoalveolar carcinoma subtypes: a Southwest Oncolgy group study. I Clin Oncol 2005, 23:6838-6845.

16. Shepherd FA, Rodrigues Pereira J, Ciuleanu T, Tan EH, Hirsh V, Thongprasert S, Campos D, Maoleekoonpiroj S, Smylie M, Martins R, van Kooten M, Dediu M, Findlay B, Tu D, Johnston D, Bezjak A, Clark G, Santabarbara P, Seymour L, National Cancer Institute of Canada Clinical Trials Group: Erlotinib in previously treated non-smallcell lung cancer. N Engl J Med 2005, 353: I23-I32.

17. Tsao MS, Sakurada A, Cutz JC, Zhu CQ, Kamel-Reid S, Squire J, Lorimer I, Zhang T, Liu N, Daneshmand M, Marrano P, da Cunha Santos G, Lagarde A, Richardson F, Seymour L, Whitehead M, Ding K, Pater J, Shepherd FA: Erlotinib in lung cancer- molecular an dclinical predictors of outcome. N Eng / Med 2005, 353: I 33- I 44

18. Mellinghoff IK, Wang MY, Vivanco I, Haas-Kogan DA, Zhu S, Dia EQ Lu KV, Yoshimoto K, Huang JH, Chute DJ, Riggs BL, Horvath S, Liau LM, Cavenee WK, Rao PN, Beroukhim R, Peck TC, Lee JC, Sellers WR, Stokoe D, Prados M, Cloughesy TF, Sawyers CL, Mischel PS: Molecular determinants of the response of glioblastomas to EGFR kinase inhibitors. N Engl ] Med 2005, 353:20I2-2024.

19. Moroni M, Veronese S, Benvenuti S, Marrapese G, Sartore-Bianchi A, Di Nicolantonio F, Gambacorta M, Siena S, Bardelli AM: Gene copy number for epidermal growth factor receptor (EGFR) and clinical response to antiEGFR treatment in colorectal cancer: a cohort study. Lancet Oncol 2005, 6:279-286.

20. Shia J, Klimstra DS, Li AR, Qin J, Saltz L, Teruya-Feldstein J, Akram M, Chung KY, Yao D, Paty PB, Gerald W, Chen B: Epidermal growth factor receptor expression and gene amplification in colorectal carcinoma: an immunohistochemical and chromogenic in situ hybridization study. Mod Pathol 2005, I 8: I350-1356.

21. van der Hout $A H$, van den Ouweland $A M$, van der Luijt RB, Gille $H J$, Bodmer D, Bruggenwirth $H$, Mulder IM, van der Vlies $P$, Elfferich $P$, Huisman MT, ten Berge AM, Kromosoeto J, Jansen RP, van Zon PH, Vriesman T, Arts N, Lange MB, Oosterwijk JC, Meijers-Heijboer H, Ausems MG, Hoogerbrugge N, Verhoef S, Halley DJ, Vos YJ, Hogervorst $F$, Ligtenberg M, Hofstra RM: A DGGE system for comprehensive mutation screening of BRCAI and BRCA2: application in a Dutch cancer clinic setting. Hum Mutat 2006, 27:654-666.

22. Goldstein NS, Armin M: Epidermal growth factor receptor immunohistochemical reactivity in patients with American Joint Committee on Cancer Stage IV colon adenocarcinoma: implications for a standardized scoring system. Cancer 200I, 92: I33।

23. Mayr D, Kanitz V, Amann G, Engel J, Burges A, Lörhs U, Diebold J: Analysis of gene amplification and prognostic markers in ovarian cancer using comparative genomic hybridization for microarrays and immunohistochemical analysis for tissue microarrays. Am J Clin Pathol 2006, I 26:101-9.

24. Vandamme B, Lissens W, Amfo K, De Sutter P, Bourgain C, Vamos E, De Greve J: Deletion of chromosome IIp/3-IIpI5.5 sequences in invasive human ovarian cancer is a subclonal progression factor. Cancer Res 1992, 52:6646-6652.

\begin{tabular}{l} 
25. splice detector program [http://www.fruitfly.org/seq tools/ \\
\hline
\end{tabular} splice.html]
26. Shigematsu H, Takahashi T, Nomura M, Majmudar K, Suzuki M, Lee H, Wistuba II, Fong KM, Toyooka S, Shimizu N, Fujisawa T, Minna JD, Gazdar AF: Somatic mutations of the HER2 kinase domain in lung adenocarcinomas. Cancer Res 2005, 65:1642-1646.

27. Cappuzzo F, Toschi L, Trisolini R, Bemis L, Subita M, Domenichini I, Franklin W, Crino L, Ciardiello F, Varella-Garcia M: Clinical and biological effects of gefitinib in EGFR FISH positive/phosphoakt positive or never smoker non-small cell lung cancer (NSCLC): Preliminary results of the ONCOBELL trial (abstract). J Clin Oncol ASCO Annual Meeting Proceedings Part I 2006, 24(I8S):7023.

28. Paz-Ares L, Sanchez JM, García-Velasco A, Massuti B, López-Vivanco G, Provencio M, Montes A, Isla D, Amador ML, Rosell R, Spanish Lung Cancer Group: A prospective phase II trial of erlotinib in advanced non-small cell lung cancer (NSCLC) patients (p) with mutations in the tyrosine kinase (TK) domain of the epidermal growth factor receptor (EGFR). (Abstract). I Clin Oncol ASCO Annual Meeting Proceedings Part I 2006, 24( I8S):7020.

29. Lassus $H$, Sihto $H$, Leminen A, Joensuu $H$, Isola J, Nupponen NN, Butzow R: Gene amplification, mutation and protein expression of EGFR and mutations in ERBB2 in serous ovarian cacrinoma. J Mol Med 2006, 84:67I-68I.

30. Ji H, Zhao X, Yuza Y, Shimamura T, Li D, Protopopov A, Jung BL, McNamara K, Xia H, Glatt KA, Thomas RK, Sasaki H, Horner JW, Eck M, Mitchell A, Sun Y, Al-Hashem R, Bronson RT, Rabindran SK, Discafani CM, Maher E, Shapiro GI, Meyerson M, Wong KK: Epidermal growth factor receptor variant III mutations in lung tumorigenesis and sensitivity to tyrosine kinase inhibitors. Proc Natl Acad Sci 2006, 103:7817-22.

3I. Stephens P, Hunter C, Bignell G, Edkins S, Davies H, Teague J, Stevens C, O'Meara S, Smith R, Parker A, Barthorpe A, Blow M, Brackenbury L, Butler A, Clarke O, Cole J, Dicks E, Dike A, Drozd A, Edwards K, Forbes S, Foster R, Gray K, Greenman C, Halliday K, Hills K, Kosmidou V, Lugg R, Menzies A, Perry J, Petty R, Raine K, Ratford L, Shepherd R, Small A, Stephens Y, Tofts C, Varian J, West S, Widaa S, Yates A, Brasseur F, Cooper CS, Flanagan AM, Knowles M, Leung SY, Louis DN, Looijenga LH, Malkowicz B, Pierotti MA, Teh B, ChenevixTrench G, Weber BL, Yuen ST, Harris G, Goldstraw P, Nicholson AG, Futreal PA, Wooster R, Stratton MR: Lung cancer: intragenic ERBB2 kinase mutations in tumours. Nature 2004 43I:525-526.

32. Stadlmann S, Gueth U, Reiser U, Diener PA, Zeimet AG, Wight E, Mirlacher M, Sauter G, Mihatsch MJ, Singer G: Epithelial growth factor receptor status in primary and recurrent ovarian cancer. Mod Pathol 2006, 19:607-6I0.

33. Lee $\mathrm{CH}$, Huntsman DG, Cheang MC, Parker RL, Brown L, Hoskins $P$, Miller D, Gilks CB: Assessment of Her-I, Her-2, Her-3 expression and Her-2 amplification in advanced ovarian carcinoma. Int J Gynecol Pathol 2005, 24: I47-52.

34. Blank S, Chang R, Muggia F: Epidermal growth factor receptor inhibitors for the treatment of epithelial ovarian cancer. Oncology 2005, 19:553-559.

35. Tsuchihashi Z, Khambata-Ford S, Nasser H, Janne PA: Responsiveness to cetuximab without mutations in EGFR. N Eng J Med 2005, 353:208-209.

36. Saltz L: Epidermal growth factor receptor-negative colorectal cancer: is there truly such an entity? Clin Colorectal Cancer 2005, 5 Suppl 2:S98-SI00.

37. Bookman MA Darcy KM, Clarke-Pearson D, Boothby RA, Horowitz IR: Evaluation of monoclonal humanized anti-HER2 antibody, trastuzumab, in patients with recurrent or refractory ovarian or primary peritoneal carcinoma with overexpression of HER2: a phase II trial of the Gynecologic Oncology Group. J Clin Oncol 2003, 21:283-290.

\section{Pre-publication history}

The pre-publication history for this paper can be accessed here:

http://www.biomedcentral.com/1471-2407/8/3/prepub 